\title{
COMPARISON OF SLOVAK AND ENGLISH WORD STRESS
}

The paper defines and describes the basic stress characteristics in general and shows its functioning in Slovak and English language. It also implies that its wrong perception contributes to Slovak-English language interference.

Key words: word stress, syllable, Slovak language, English language, comparison.

\section{Introduction}

As Deborah Cameron puts it, "speech is organized into prosodic units, marked off by pauses and intonation contours: they may or may not have the syntactic structure of complete sentences. Writing, however, relies on the sentence as its basic unit" [1]. Word stress is one of the principal prosodic qualities of speech. It can be defined as "the relative degree of force with which a syllable is uttered" [2].

Prosodic features of speech include variation in syllable length, loudness, pitch, and the formant frequencies of speech sounds. They might reflect various features of a speaker or utterance, the emotional state of the speaker; the form of the utterance (statement, question, or command); possibly irony or sarcasm; emphasis, contrast, and focus; or other possible elements of language (not encoded by grammar or choice of vocabulary).

The question is: how do we distinguish the stressed and unstressed syllables? Peter Roach [3, p. 93-94] mentions two different ways of approaching this problem. The first one is consideration "what the speaker does in producing stressed syllables and the other one is consideration what characteristics of sound make a syllable seem to a listener to be stressed," so we can basically speak about production and perception. It is generally believed that the production of stress depends on speaker using more muscular energy than for unstressed syllables. Measuring this effort is difficult, but not impossible. From the point of perception all stressed syllables show a certain common characteristics that is prominence. The prominence of stressed syllables can be characterized by these features:

- most people seem to perceive that the stressed syllables are louder than the unstressed ones,

- the stressed syllable is usually perceived as longer,

- the stressed syllables are pronounced on a different pitch level,
- the stressed syllable usually contains a vowel whose quality is different from the neighbouring vowels.

We distinguish between several types of stress [4]:

- dynamic or force stress, gained by greater force in articulation with the result of higher loudness and intensity,

- quantitative stress, gained by quantity i.e. duration of the sound, - qualitative stress, gained by different quality of vowels in stressed and unstressed vowels,

- musical stress, typical for Japanese or Vietnamese, in these languages the prominence is achieved by variation of pitch level.

The place of the stress can be fixed on a certain syllable, e.g. initial in Finnish, penultimate in Polish and the last one in French, or random, as in English. It can often be predictable in English, but many authors have stated, that " English stress is so difficult to predict that it is the best to treat stress placement as a property of the individual word, to be learned when the word itself is learned [5, p.97].

Stress is a relational and gradual feature, since we describe it in terms of prominence of certain elements in comparison to others. Therefore, there are no absolute degrees - maximal stress and no stress at all - and we can only say that some structures display this feature to a greater extent than other. In general, we recognize primary, secondary and weak stress.

Teaching prosodic features of language has a special importance when we realize that successful communication hugely depends on intonation, stress, rhythm and the correct pronunciation of sounds. Recently it also has gained a lot of attention that can be associated with studying phonetic structure of language due to fastly developing fields where using automated voice applications is becoming more and more important and useful. The knowledge of phonetics can also be applied in the modern applications of automated speech understanding, dialogue systems for voice ordering of goods and

\footnotetext{
* Lenka Mocova

Institute of Foreign Languages, University of Zilina, Slovakia; E-mail: lenka.mocova@ucj.uniza.sk
} 
services, automated spech translation, as well as in the research of bio-cognitive functions of human mind [6, p. 114].

\section{Slovak Word Stress}

In Slovak language the primary word stress is fixed on the first syllable. The secondary word stress occurs in words with more than 4 syllables and is fixed on the penultimate syllable. The word stress in Slovak has a deliminative function which means that its presence marks the beginning of the word, its absence the end of a word. Some regional accents put the word stress on different place, e.g. some accents in Eastern Slovakia, such as Zemplín.

The rules for placing stress in expressions with a preposition are more complex. The prepositions with more syllables such as medzi, popred, ponad, mimo, vôkol etc. are stressed on the first syllable as any other words, whereas the one-syllable prepositions as $s, z, v, k$, pred, nad, za, po, pri etc. might be but do not have to be stressed. Here, the general context is crucial - the contextual meaning of preposition, the speaker's attitude, and others. The one-syllable prepositions are also stressed in idiomatic expressions e.g. robit o dusu; na zivot a na smrt [7]. In general, there is a tendency towards stressing the preposition.

The unstressed word that is connected to the preceding word is called enclitic. These are: one-syllable words e.g. forms of auxiliary verb to be: som, si, je, ste, su, sme, and pronouns such as $t i, m i$, $m u$, jej, vas, ich, etc. The unstressed words that precede the stressed syllable and are connected to them in the speech are called proclictics.

\section{English Word Stress}

The position of word stress in English language is changeable, but often predictable. There are 11 stress patterns altogether. Very simply said, in short and morphologically simple words it is often placed on the first syllable, in longer and morphologically more complex words on other than first syllable. However, English word stress placement is a rather complex issue. To decide correctly, one has consider the morphological complexity of a word, the grammar category, the number of syllables and the phonological structure of a syllable [8, p. 97]. Peter Roach [9, p. 97-100] brings a summary of basic word stress rules:

Single-syllable words do not present any special problems, they are always pronounced as stressed. Concerning two-syllable words, one of two syllables is stressed, not both. Let us describe the behavior of individual word categories, starting with verbs. Here, if the second syllable of a verb is a strong syllable, then it is stressed. E.g. apply - ə'plai. If the final syllable is weak, the first syllable is stressed, e.g. envy - 'envi. A final syllable is also unstressed if it contains əə, e.g. follow - 'folə stressed in the same way e.g. even - i:vn, alive - ə’laiv. The nouns are stressed in a different way. If a second syllable contains a short vowel, then the stress normally comes on the first syllable, if not it will stay on the second syllable. E. g. estate - i'steit, design di'zain. Other two-syllable words seem to act like verbs and adjectives.

Concerning three-syllable words, the situation is a bit more complicated. Let us start with verbs. If the third syllable is strong, it will be stressed. E.g. entertain - ento'tein. If the last one is weak i.e. unstressed, the stress will be on the penultimate syllable. If the second and third syllables are weak, then the stress will be on the first syllable. The nouns behave differently. If the final syllable is weak or ends with $ə \mho$, it is unstressed, if the penultimate syllable is strong, then the middle one will be stressed. E. g. potato p’teitə $\mho$. If the second and third syllables are weak, the first syllable is stressed. E.g. cinema - 'sintəmtə. Three- syllable simple nouns present a new situation, because here even if the final syllable is strong, the stress will be on the first syllable. As P. Roach [10] adds," the last syllable is usually quite prominent, so that in some cases it could have been said to have secondary stress." E. g. intellect - "intə.lekt. The adjectives behave in the same way, unlike other word categories. The rules are far more complex and complicated, feature a lot of exceptions, thus we cannot cover them all here.

The word stress in English performs several functions [11]:

1. Constitutive. The stress pattern helps to build a word, without it the word would be non-existent.

2. Distinctive. Here, the stress pattern differentiates the words with analogous sound structure.

3. Identificatory. The word stress helps identify combinations of sounds as meaningful linguistic units.

The word stress in English has a dynamic nature, either dynamic qualitative or dynamic quantitative. It is normally demonstrated by the raise of intensity or duration of a syllable, sharpening of the vowel spectrum, the fundamental frequency can rise or fall or there might occur a combination of all there symptoms.

English word stress often has a distinctive function in word compounds. E. g. If we stress the word green in the expression green house this would suggest we want to mention greenhouse/sklenik, if we stress green as well as house, it suggests we want to mention a house of green colour [12, p. 38]. This can cause certain language interference as the Slovak speakers of English tend to pronounce each word as stressed.

\section{Comparison}

The English and Slovak word stresses differ in many ways. The difference in position is the most obvious one, in Slovak it is fixed on the first syllable, in English it can have any position. In general, the difference in the intensity and vocalic quality between the stressed and unstressed syllables is more noticeable and stronger in English than in Slovak. English unstressed syllables show a significant reduction of vowel quality, whereas in Slovak the vowel quality remains the same in stressed or unstressed syllables [13, p. 37-39]. 
Here, we can notice the neutralization of unstressed vowels closer to schwa[ ]. The unstressed syllable is almost always changed to neutral vowel schwa that is rare in Slovak. (It is only used by pronouncing the alphabet letters or in the speech breaks to signal thinking) [14, p. 22-23]. English as well as Slovak uses dynamic word stress, but they differ in the force; English word stress ranks among the strongest whereas the Slovak stress is one of the weakest among European languages. In the expressions with a preposition, in English there is a tendency towards stressing the noun, in Slovak the preposition [15].

It is very interesting to notice how recent penetration of anglicisms into Slovak language has been reflected in the field of pronunciation. According to Z. Katreniaková, the signs of phonetic adaptation of anglicisms in Slovak language might be: the change of foreign word stress to Slovak word stress, i.e. to the first syllable, the change of vowel quantity (usually by replacement of a short vowel by a long one), replacement of phonemic groups that Slovak language does not have and the change of unvoiced $s$ between vowels to voiced $\mathrm{z}[16, \mathrm{p} .7]$.

The research of Z.Kralova (2005) performed at the sample of 60 Slovak students with the aim of determining the dominant features of segmental and suprasegmental system that make the communication more difficult and contribute to English-Slovak language interference, has clearly shown that word stress is one of the key factors when comes to English-Slovak language interference.
$47.06 \%$ of all phonic mistakes were caused by placing the word stress in a wrong position $[17$, p. 22].

\section{Conclusion}

The position and functioning of stress in English and Slovak differ significantly. The English culminative stress that has a distinctive function is systematically more rigorous than the demarcative stress with delimitative function in the Slovak language [18].

Such an obvious difference between these two suprasegmental systems often causes a phenomenon known as language interference that includes all the possible communication problems and misunderstandings. E.g. the Slovak speakers often shift the stress to the first syllable in English words, being influenced by the Slovak concept of fixed stress.

Being university teachers, we often notice not much attention has been given to learning pronunciation. This frequently leads to inability to communicate when the students are exposed to "real English" in a future profession or possibly in an English speaking country.

\section{Acknowledgements}

This research was supported by the grant KEGA No. 085ZU4/2011 of the Ministry of Education, Science, Research and Sport of the Slovak Republic.

\section{References}

[1] CAMERON, D.: The Teacher's Guide to Grammar. Oxford University Press, 2007.

[2] JONES, D.: An Outline of English Phonetics, [Retrieved 2011], <http://www.scribd.com/doc/60719467/Daniel-Jones-An-Outline-ofEnglish-Phonetics>

[3] ROACH, P.: English Phonetics and Phonology, Cambridge, Cambridge University Press, 2005.

[4] MYTKALYK, T.: Theoretical Phonetics, Handouts 16, [Retrieved 2011], <http://www.scribd.com/doc/57366073/Theoretical-Phonetics-Handouts-1-6>

[5] ROACH, P.: English Phonetics and Phonology, Cambridge, Cambridge University Press, 2005.

[6] BENUS, S.: Teaching Foreign Language Pronunciation with the Help of Comparative Acoustic Analysis (in Slovak), Filozoficka fakulta UKF Nitra, 2010.

[7] STUlAJTEROVA, A.: To the Problem of Adaptation of New Anglicisms in the System of Slovak Language (in Slovak) [Retrieved 2011] 〈www2.fhv.umb.sk/Katedry/.../zbornik\%203/089-106stulajterova.doc >

[8] ROACH, P.: English Phonetics and Phonology, Cambridge, Cambridge University Press, 2005.

[9] ROACH, P.: English Phonetics and Phonology, Cambridge, Cambridge University Press, 2005.

[10] ROACH, P.: English Phonetics and Phonology, Cambridge, Cambridge University Press, 2005.

[11] MYTKALYK, T.: Theoretical Phonetics, Handouts 16, [Retrieved 2011] <http://www.scribd.com/doc/57366073/Theoretical-Phonetics-Handouts-1-6>

[12] BENUS, S.: Teaching Foreign Language Pronunciation with Comparative Acoustic Analysis (in Slovak), Filozoficka fakulta UKF Nitra, 2010.

[13] BENUS, S.: Teaching Foreign Language Pronunciation with Comparative Acoustic Analysis (in Slovak), Filozoficka fakulta UKF Nitra, 2010.

[14] KRALOVA, Z: Slovak-English Phonic Interference (in Slovak), Faculty of Science, University of Zilina, 2005.

[15] KRALOVA, Z: Slovak-English Phonic Interference (in Slovak), Faculty of Science, University of Zilina, 2005.

[16] cited in STULAJTEROVA, A.: To the Problem of Adaptation of New Anglicisms in the System of Slovak Language (in Slovak), [Retrieved 2011] <www2.fhv.umb.sk/Katedry/.../zbornik\%203/089-106stulajterova.doc〉

[17] KRALOVA, Z: Slovak-English Acoustic Interference (in Slovak), Faculty of Science, University of Zilina, 2005.

[18] KRALOVA, Z: Slovak-English Phonic Interference (in Slovak), Faculty of Science, University of Zilina, 2005. 